ГORIGINAL ARTICLE-

Volume 13 Issue 32021

DOI: 10.21315/eimj2021.13.3.5

ARTICLE INFO

Received: 29-03-2020

Accepted: 19-05-2021

Online: 30-09-2021

\section{Project-Based Learning Strategy for Teaching Molecular Biology: A Study of Students' Perceptions}

\author{
Ayman Z. Elsamanoudy ${ }^{1,2}$, Fayza Al Fayez ${ }^{1}$, Aliaa Alamoudi' ${ }^{1}$, \\ Zuhier Awan' ${ }^{1}$, Abdulhadi I. Bima', Fatma M. Ghoneim³ \\ Mohammed Hassanien ${ }^{4,5}$
}

${ }^{1}$ Department of Clinical Biochemistry, Faculty of Medicine, King Abdulaziz University, feddah, SAUDI ARABIA

${ }^{2}$ Medical Biochemistry and Molecular Biology, Faculty of Medicine, Mansoura University, Mansoura, EGYPT

${ }^{3}$ Faculty Development Unit, Department of Medical Education, Fakeeh College for Medical Sciences, feddah, SAUDI ARABIA

${ }^{4}$ Vice Presidency for Educational Affairs and College of Pharmacy, King Abdulaziz University, feddah, SAUDI ARABIA

${ }^{5}$ Department of Medical Biochemistry, College of Medicine, Tanta University, Tanta, EGYPT

To cite this article: Elsamanoudy AZ, Fayez FA, Alamoudi A, Awan Z, Bima AI, Ghoneim FM, Hassanien M. Project-based learning strategy for teaching molecular biology: a study of students' perceptions. Education in Medicine Journal. 2021;13(3):43-53. https://doi.org/10.21315/ eimj2021.13.3.5

To link to this article: https://doi.org/10.21315/eimj2021.13.3.5

\title{
ABSTRACT
}

This current study aims to analyse students' perceptions regarding implementing project-based learning $(\mathrm{PjBL})$ in teaching a molecular biology course to second-year pharmacy students at King Abdulaziz University as a sort of active student-centred learning method. Sixty-five male and 90 female students were enrolled in this study. This research used survey instruments to assess learners' perceptions. The survey was divided into four sections that consisted of closedended questions to evaluate students' overall perceptions of PjBL, communication skills, project management and teamwork activity during their project management process. A 5-point Likert scale was used. Regarding overall learning and students' satisfaction with the PjBL experience, the percentage was $72.73 \%$, with a score of 21.82 over 30 . The percentage of students' perceptions towards the improvement of their communication skills was $60.98 \%$, with a score of 15.25 over 25. The percentage of students' perceptions of project management skills was $64.97 \%$, with a score of 12.99 over 20. Finally, regarding teamwork, the survey revealed a percentage of $71.81 \%$, with a score of 43.08 over 60 . There was a positive correlation between students' perceptions of the questionnaire's four parts and their grade point average (GPA) in the molecular biology course. It can be concluded that PjBL is an effective tool in the active-learning process. 
PjBL can improve students' communication and management skills. Also, it encourages teamwork activities between students.

Keywords: Feedback, Perception, Project-based learning, Molecular biology King Abdulaziz University, Jeddah, 21465, Saudi Arabia

Medical Biochemistry and Molecular Biology, Faculty of Medicine, Mansoura University, 35516, Mansoura, Egypt

Email: ayman.elsamanoudy@gmail.com

\section{INTRODUCTION}

Project-based learning ( $\mathrm{PjBL})$ is defined as an individual or group activity carried out over an extended period with a timeline. Its product could be in the form of a presentation and/or performance. PjBL can consist of several milestones and include other aspects of formative evaluation as the project proceeds (1). PjBL gives students meaningful insight into the exploration, creation, interpretation, negotiation and product development process, namely the writing and presentation of necessary documentation (2).

PjBL's advantages go beyond workplace abilities to other teaching methods and other soft abilities during the project implementation. PjBL's main benefit is that it can ensure more students' interest, enhance their interactivity, substitute for teaching and induce greater understanding and reflection of the subject of study (3). Also, its student-centred approach, which focuses more on students rather than teachers, is a fundamental advantage of PjBL (4).

Using PjBL could be directed mainly to provide disciplinary learners with stimulating, workplace-like situations to attain their learning objectives. It aims to expose learners to the actual globe, encourage entrepreneurial thinking and develop soft skills that help them adapt to the competitive, scientific work environment (5-6).
A molecular biology course is taught to second-year students as part of medical biochemistry and molecular biology science in the Faculty of Pharmacy, King Abdulaziz University (KAU). The traditional teaching methods remain the predominant method and comprise lectures and practical sessions. Student assessment is carried out by summative assessment methods in the form of a final written exam composed of multiple choice questions (MCQs) for evaluating knowledge and cognitive course objectives and a practical exam for evaluating psychomotor objectives.

In this current study, implementing small projects for students was a trial of incorporating them into an interactive, student-centred method of teaching and learning. This study aims to discuss the feedback and perceptions of students regarding implementing $\mathrm{PjBL}$ in teaching the molecular biology course to secondyear pharmacy students at KAU as a sort of active student-centred learning method. Thus, the research question we aspired to address in the current study is: How did second-year pharmacy students perceive this course's new learning method?

\section{METHODS}

This study was carried out in the Faculty of Pharmacy at KAU in Jeddah, Saudi Arabia. It included the use of survey instruments to assess the perceptions of learners regarding implementing $\mathrm{PjBL}$ in the molecular biology course. This study was directed towards second-year students $(65$ males 
and 90 females) during the 2018 to 2019 second semester-a three-credit-hour course, with two contact hours per week for one semester.

\section{Project Implementation}

This study was conducted while teaching the molecular biology course (clinical biochemistry) for second-year students at Faculty of Pharmacy, KAU, Saudi Arabia. The students were divided into small groups (seven students per group). Each group was assigned to implement a specific project as a team. These projects included a literature review, case study discussion, problem solving and illustration of some molecular biology techniques. The projects' topics were: the molecular basis of cancer development, the molecular basis of chemotherapeutic agents, the genetic background of metastasis and cancer recurrence, the genetic basis of hyperuricemia, mutagenesis and the defective DNA repair mechanism about cancer.

All students were subjected to two orientation workshop sessions (45 minutes for each session). The workshop aimed to learn the basics of the PjBL strategy and the implementation and assessment methods. The students' roles were explained, as they had to write the project's objectives, design the project plan, design the project hierarchy and create a doable schedule, collect data from scientific textbooks and websites, use multimedia and other illustration tools while presenting their project, establish and assess the outcome, and discuss their projects with their peers and the instructor.

The students were instructed to work as a team, effectively communicate with each other and with their instructor and prepare to present their projects by using PowerPoint. The project's duration was seven weeks. The students presented their projects in the eighth week, as scheduled in the project's time plan. The students were asked to present their work while critically appraising the contents and opening discussions with their instructors and peers. Finally, the students were assessed using a rubric sheet prepared and approved by the instructors.

\section{The Survey}

The survey was created by Sang and Van (7), with minor modifications and was validated. The questionnaire's validation was initially carried out by precursory pilot testing of the questionnaire (15 male and 15 female students), and subsequent revising of the questionnaire result was followed by double-blind revision by two senior experts from the medical education department.

The survey was divided into four sections consisting of closed-ended questions. The first section included questions that measured the general students' perception of PjBL. The second section included questions related to communication skills. The third section evaluated their perceptions of project management. The fourth section included questions about the usage of teamwork activity during their project management process. A 5-point Likert scale was used, with 1 being the lowest scale and 5 being the highest $(1=$ strongly disagree, $2=$ disagree, $3=$ neutrals, $4=$ agree, $5=$ strongly agree). After the session, the questionnaire was distributed to all students. All data were provided anonymously.

All students participated in this survey study. Evaluating the projects was included in the formative assessment. Students were evaluated through the rubric assessment sheet, based on their active participation during the two-hour discussion session, to evaluate all points targeted by the project.

\section{Statistical Methods}

Data were analysed using the SPSS software version 23 (SPSS, Inc., Chicago, IL, USA). Quantitative parametric data were presented as mean and standard deviations, while quantitative non-parametric data were presented as median and range. 
Qualitative data were presented as frequency (number-percent). A one-way ANOVA test (followed by a Tukey post hoc test) was used to compare more than two different groups with parametric data. Spearman's correlation was used to correlate the totals of the questionnaires, gender and grade point average (GPA). A Cronbach's alpha test was used to assess the questionnaire's reliability. A $p$-value of less than 0.05 was considered statistically significant.

\section{RESULTS}

The study involved second-year pharmacy students during the molecular biology section of their clinical biochemistry course. The numbers of students, gender and total GPA are presented in Table 1 . The number

Table 1: Gender and total GPA of the participants

\begin{tabular}{llcc} 
Variables & & Total & $\%$ \\
\hline Gender & Male & 65 & 41.9 \\
& Female & 90 & 58.1 \\
Total GPA & $>4.5$ & 38 & 24.5 \\
& $3.5-4.49$ & 92 & 59.4 \\
& $2.5-3.49$ & 15 & 9.7 \\
& $<2.5$ & 10 & 6.5 \\
\hline
\end{tabular}

of participating students in the current study was 155 including 65 males (41.9\%) and 90 females (58.1\%). The participants' GPAs were distributed according to the normal distribution of grades $(24.5 \%>4.5$, $59.4 \%$ at $3.5-4.49,9.7 \%$ at $2.5-3.49$ and $6.5<2.5)$.

The results of the reliability testing are presented in Table 2, as a Cronbach's alpha test was used to assess the reliability of the questionnaires. All components of the questionnaire sectors showed good reliability, as stated in Table 2 (for the four groups of questionnaire components).

Regarding students' overall learning and satisfaction with their $\mathrm{PjBL}$ experience, an average score of 21.82 out of 30 was seen, indicating $72.73 \%$ overall satisfaction (Table 3). The percentage of students' perceptions regarding the improvement of their communication skills through $\mathrm{PjBL}$ was $60.98 \%$, with a score of 15.25 out of 25 (Table 4). Regarding the effect of PjBL on project management skills, the percentage of students' perceptions was $64.97 \%$, with a score of 12.99 out of 20 (Table 5). Finally, teamwork showed the secondhighest percentage and score following overall satisfaction, since the percentage of students' perceptions was $71.81 \%$, with a mean score of 43.08 out of 60 (Table 6 ).

Table 2: Reliability tests of the perception questionnaires (Students' perceptions of PjBL in teaching Molecular Biology)

\begin{tabular}{lccccc}
\hline Questionnaires & $\begin{array}{c}\text { Number } \\
\text { of items }\end{array}$ & $\begin{array}{c}\text { Cronbach's } \\
\text { alpha }\end{array}$ & Mean & Variance & SD \\
\hline $\begin{array}{l}\text { First questionnaire: } \\
\quad \text { Overall learning and student's } \\
\text { satisfaction }\end{array}$ & 6 & 0.86 & 21.819 & 28.084 & 5.2994 \\
$\begin{array}{l}\text { Second questionnaire: } \\
\quad \text { Communication skills }\end{array}$ & 5 & 0.84 & 15.245 & 27.264 & 5.2215 \\
$\begin{array}{l}\text { Third questionnaire: } \\
\quad \text { Project management activity }\end{array}$ & 4 & 0.76 & 13.203 & 15.407 & 3.9252 \\
$\begin{array}{l}\text { Fourth questionnaire: } \\
\quad \text { Teamwork activity }\end{array}$ & 12 & 0.86 & 43.084 & 67.376 & 8.2083 \\
\hline
\end{tabular}


Table 3: Students' perceptions of PjBL in teaching Molecular Biology: Overall learning and students' satisfaction

\begin{tabular}{lcc}
\hline Overall learning and students' satisfaction & Median & Range \\
\hline PjBL improved my understanding of course topics & 4 & $2-5$ \\
PjBL improved my teamwork and collaboration skills & 4 & $2-5$ \\
PjBL improved my self-regulation and self-learning skills & 4 & $1-5$ \\
PjBL improved my communication skills & 4 & $2-5$ \\
PjBL prepared me for a professional career and lifelong learning success & 4 & $1-5$ \\
Working in groups through PjBL was enjoyable & 3 & $2-5$ \\
Total score (out of 30) [mean $\pm S D]$ & \multicolumn{2}{c}{$21.82 \pm 5.30$} \\
Percentage of total score [mean $\pm S D]$ & \multicolumn{2}{c}{$72.73 \pm 17.66$} \\
\hline
\end{tabular}

Notes: Data are presented as median and range [nonparametric data] and mean \pm SD for total scores [parametric data]. The level of agreement was described using a 5-point Likert scale.

Table 4: Students' perceptions of PjBL in teaching Molecular Biology: Communication skills

\begin{tabular}{lcc}
\hline Communication skills & Median & Range \\
\hline I learned to write e-mails related to workplace settings & 3 & $1-5$ \\
I responded well to e-mails I received related to the project assigned & 3 & $2-4$ \\
I become familiar with the writing format and style of workplace e-mails & 3 & $1-5$ \\
Ilearned to organise ideas in preparing and writing the executive summary & 3 & $1-5$ \\
Ilearned how to write reports based on the findings & 3 & $1-5$ \\
Total score (out of 25) [mean $\pm S D]$ & $15.25 \pm 5.22$ \\
Percentage of total score [mean $\pm S D]$ & $60.98 \pm 20.89$ \\
\hline
\end{tabular}

Notes: Data are presented as median and range [nonparametric data] and mean \pm SD for total scores [parametric data]. The level of agreement was described using a 5-point Likert scale.

Table 5: Students' perceptions of PjBL in teaching Molecular Biology: Project management activity

\begin{tabular}{lcc}
\hline Project management activity & Median & Range \\
\hline l am confident to give suggestions freely among group members & 4 & $1-5$ \\
$\begin{array}{l}\text { I learned how to brainstorm and forward ideas appropriately with } \\
\text { group members }\end{array}$ & 4 & $1-5$ \\
$\begin{array}{l}\text { I understand and able to gather information for the project } \\
\text { Ilearned how to identify the relevant ideas from reading materials }\end{array}$ & 3 & $2-5$ \\
regarding project work & & $2-5$ \\
Total score (out of 20) [mean $\pm S D]$ & $12.99 \pm 3.59$ \\
Percentage of total score [mean $\pm S D]$ & $64.97 \pm 17.97$ \\
\hline
\end{tabular}

Notes: Data are presented as median and range [nonparametric data] and mean \pm SD for total scores [parametric data]. The level of agreement was described using a 5-point Likert scale. 
Table 6: Students' perceptions of PjBL in teaching Molecular Biology: Teamwork activity

\begin{tabular}{lcc}
\hline Teamwork activity & Median & Range \\
\hline I learned how to listen actively to my group members & 2 & $2-5$ \\
I learned how to ask and respond appropriately among group members & 3 & $2-5$ \\
I learned how to be assertive when exchanging ideas with group members & 4 & $2-5$ \\
I learned that good team-work contributes to a successful outcome of the project & 4 & $3-5$ \\
I prefer team-based learning (TBL) to normal lectures & 4 & $3-5$ \\
TBL strategy motivated me to study hard & 4 & $2-5$ \\
I look forward to learn again in a TBL course & 4 & $2-5$ \\
TBL challenged me to give my best & 4 & $2-5$ \\
TBL helped me learn how to study in a group & 3 & $2-5$ \\
I frequently studied with my colleagues & 3 & $1-5$ \\
Discussion during group work for preparing topic helped me comprehend better & 3 & $2-5$ \\
TBL required more hard work by the students & 3 & $1-5$ \\
Total score (out of 60 ) [mean $\pm S D$ ] & $43.08 \pm 8.21$ \\
Percentage of total score [mean $\pm S D$ ] & $71.81 \pm 13.68$ \\
\hline
\end{tabular}

Notes: Data are presented as median and range [nonparametric data] and mean \pm SD for total scores [parametric data]. The level of agreement was described using a 5-point Likert scale.

Students' perceptions at different GPA levels showed a statistically significant difference between the students at each level when compared to each other (ANOVA $p<0.05)$ for the questionnaire's four components. The high achieving students (with a GPA > 3.5) revealed more positive satisfaction and better perception than those who were low achievers (with a GPA of 3.5), as presented in Table 7 .

Regarding the correlation between students' GPA and their perceptions regarding $\mathrm{PjBL}$ implementation, there was a significant positive correlation between students' perceptions of the four parts of the questionnaire and their GPA in the molecular biology course, with $r$ values of $0.209(p<0.01), 0.245(p<0.01), 0.529$ $(p<0.001)$ and $0.283(p<0.001)$, respectively (see Table 8). However, there was no significant correlation between students' perceptions of the questionnaire's four parts and their gender (see Table 8).

\section{DISCUSSION}

This current study aimed to evaluate students' perceptions regarding implementing $\mathrm{PjBL}$ in teaching a molecular biology course to second-year pharmacy students at KAU as an active studentcentred learning method.

The main objectives of implementing PjBL are to use a non-traditional method of teaching, especially in molecular biology, as it contains challenging concepts that are difficult to teach by traditional didactic strategies. Also, PjBL can improve other skills and competencies, which include (but are not limited to) communication skills, project management and teamwork.

The questionnaire used to evaluate students' perceptions was divided into four parts: communication skills, project management skills, teamwork and overall evaluation of the $\mathrm{PjBL}$ process. 
Table 7: Students' perceptions of PjBL in teaching Molecular Biology at different GPA score

\begin{tabular}{|c|c|c|c|c|c|c|}
\hline \multirow{2}{*}{ Questionnaire } & & \multicolumn{4}{|c|}{ Total GPA } & \multirow{2}{*}{$p$-value } \\
\hline & & $>4.5$ & $3.5-4.49$ & 2.5-3.49 & $<2.5$ & \\
\hline \multirow{2}{*}{$\begin{array}{l}\text { First questionnaire: } \\
\text { Overall learning and } \\
\text { students' satisfaction }\end{array}$} & Total & $19.16 \pm 5.36$ & $23.05^{\mathrm{a}} \pm 4.84$ & $21.00 \pm 5.48$ & $21.80 \pm 5.67$ & $0.001^{*}$ \\
\hline & $\begin{array}{l}\% \text { of total } \\
\text { score }\end{array}$ & $63.86 \pm 17.85$ & $76.85^{\mathrm{a}} \pm 16.14$ & $70.00 \pm 18.26$ & $72.66 \pm 18.91$ & $0.001^{*}$ \\
\hline \multirow{2}{*}{$\begin{array}{l}\text { Second questionnaire: } \\
\text { Communication skills }\end{array}$} & Total & $18.32 \pm 2.23$ & $14.39 \mathrm{a} \pm 5.52$ & $13.53^{a} \pm 5.68$ & $14.00 \pm 5.83$ & $<0.001^{*}$ \\
\hline & $\begin{array}{l}\% \text { of total } \\
\text { score }\end{array}$ & $73.26 \pm 8.93$ & $57.57^{a} \pm 22.08$ & $54.13^{\mathrm{a}} \pm 22.72$ & $56.00 \pm 23.32$ & $<0.001^{*}$ \\
\hline \multirow{2}{*}{$\begin{array}{l}\text { Third questionnaire: } \\
\text { Project management } \\
\text { activity }\end{array}$} & Total & $15.32 \pm 2.23$ & $12.70^{\mathrm{a}} \pm 3.82$ & $10.20^{\mathrm{ab}} \pm 1.37$ & $11.10^{\mathrm{a}} \pm 3.07$ & $<0.001^{*}$ \\
\hline & $\begin{array}{l}\% \text { of total } \\
\text { score }\end{array}$ & $76.58 \pm 11.16$ & $63.48^{\mathrm{a}} \pm 19.10$ & $51.00^{\mathrm{ab}} \pm 6.87$ & $55.50^{\mathrm{a}} \pm 15.36$ & $<0.001^{*}$ \\
\hline \multirow{2}{*}{$\begin{array}{l}\text { Fourth questionnaire: } \\
\text { Teamwork activity }\end{array}$} & Total & $34.05 \pm 10.26$ & $46.33^{\mathrm{a}} \pm 4.91$ & $44.80^{\mathrm{a}} \pm 2.40$ & $45.00^{\mathrm{a}} \pm 2.58$ & $<0.001^{*}$ \\
\hline & $\begin{array}{l}\% \text { of total } \\
\text { score }\end{array}$ & $56.76 \pm 17.11$ & $77.21^{\mathrm{a}} \pm 8.18$ & $74.66^{\mathrm{a}} \pm 3.99$ & $75.00^{\mathrm{a}} \pm 4.30$ & $<0.001^{*}$ \\
\hline
\end{tabular}

Notes: Data are presented as mean \pm SD for total scores [parametric data].

$\mathrm{a}=$ significance vs. $(>4.5)$ category $(p<0.05),{ }^{b}=$ significance vs. $(3.5-4.49)$ category $(p<0.05)$.

One-way ANOVA followed by post-hoc Tukey was used to compare between the groups of students at different GPA scores.

Table 8: Correlation between PjBL students' perceptions, and students' gender and GPA

\begin{tabular}{lccc}
\hline Questionnaire & & Gender & Total GPA \\
\hline TOTAL 1 1 & $r$ & 0.015 & 0.209 \\
First questionnaire: Overall learning and students' satisfaction & $\mathrm{P}$ & 0.851 & $0.009^{*}$ \\
TOTAL 2 & $r$ & 0.016 & 0.245 \\
Second questionnaire: Communication skills & $\mathrm{P}$ & 0.841 & $0.002^{*}$ \\
TOTAL3 & $r$ & 0.010 & 0.529 \\
Third questionnaire: Project management activity & $\mathrm{P}$ & 0.906 & $<0.001^{*}$ \\
TOTAL 4 & $\mathrm{r}$ & 0.014 & 0.283 \\
Fourth questionnaire: Teamwork activity & $\mathrm{P}$ & 0.863 & $<0.001^{*}$ \\
\hline
\end{tabular}

Notes: Spearman's correlation was used to correlate between PjBL students' perceptions, and students' gender and GPA. * indicates significant correlation value; $<0.05$ is considered significant.

$\mathrm{PjBL}$ is one of the active teaching strategies utilised by many medical colleges, as it emphasises teamwork and thus has become an essential element of several undergraduate medical programmes. Collaborative teamwork is extensively accepted as an efficient teaching approach that can enhance students' skills in acquiring and applying knowledge, communication, teamwork, organisation, leadership and time management (8-9). Therefore, the role of $\mathrm{PjBL}$ in science, technology, engineering and mathematics (STEM) education has gained much interest since the beginning of the 21 st century (10). The goal of PjBL methodologies is mainly to move passive traditional education tools towards more student-centred, enquiry-based, activelearning methods and developing problemsolving and thinking skills (10-11), all of which fit the constructivist learning method (12). Conceptual achievement and academic motivation are additional gains of applying PjBL (13). 
The Next Generation Science Standards (NGSS) calls for a new approach to science education, helping students to create, invent and think like scientists. It is recommended to encourage them to develop hypotheses, gather data, experiment, analyse data and draw conclusions. It is preferable to support them in using evidence and arguments based on findings to criticise problems and design solutions. This active approach is adopted and welcomed by the educational and research community (14), and it can be achieved by applying the PjBL method, as in this current study.

Investigating students' perceptions and feedback is a key strategy for improving learning, teaching and outcome-based curriculums (15). Indeed, students' perceptions and understanding of the applied PjBL's purpose is an important determinant for achieving the required $\mathrm{PjBL}$ outcomes (16-18). Therefore, we aimed to study students' perceptions about different aspects of $\mathrm{PjBL}$ implementation to evaluate its effectiveness in teaching molecular biology.

This present study's results show that second-year pharmacy students, at all levels of the questionnaire, agreed on the positive effect of the PjBL method. A high percentage and score were found regarding students' overall learning and satisfaction with their PjBL experience. This indicates an improvement in their understanding of course topics, self-regulation and selflearning skills. PjBL could thus be a good strategy for preparing students for a professional career and lifelong learning success.

The students also preferred TBL over normal lectures, as it motivates them to study hard and challenges them to give their best. PjBL helped students study in groups rather than individually, which helped them comprehend the material better. Students also realised that $\mathrm{PjBL}$ requires more study effort compared to traditional didactic methods.
These results are in agreement with Gavin (19), Bender (20) and were recently confirmed by Si (21). Si's study included 40 second-year pre-medical students. They implemented $\mathrm{PjBL}$ as a learning strategy in their developed course. Si's results revealed that the students' learning experiences were developed and updated, with positive responses for learning satisfaction with the course in general. Therefore, it was concluded that $\mathrm{PjBL}$ is an effective and efficient learning strategy for undergraduate students (21).

In this current study, students (at all levels of the questionnaire) were satisfied with communication skills, project management skills and teamwork activities. These results reflected the improvement in their writing skills and responding to e-mails related to workplace settings, organising ideas in preparing and writing the executive summary and writing reports based on the findings. These results also indicated improvement of communication skills between students and their colleagues and with their faculty, especially non-verbal communication.

Ishikawa et al. (22) and Liu et al. (23) reported similar results, as emphasised by Park and Park (24) in their studies. Ishikawa et al. (22) tested students' awareness and performance of communication skills by developing a course on non-verbal communication. They applied the course to 106 pre-clerkship medical students divided into 14 subgroups (to establish a teamwork activity). The students showed a significant positive perception. So, Ishikawa et al. documented that non-verbal communication, especially during teamwork activity, is an effective tool during project management (22).

The questionnaire score revealed the improvement of project management skills, especially those related to increased confidence to offer suggestions freely among group members, learning how to brainstorm and forward ideas appropriately with group 
members, the understanding of and ability to gather information for the project and identifying relevant ideas from reading materials regarding project work.

The importance of acquiring project management skills for health care providers and medical field students, including pharmacy students, was documented by Ojiako et al. (25). They concluded that the delivery of project management programmes in higher education is a mandatory task that is in agreement with recent transformational and social learning theories; therefore, educators must teach and train their students in project management to become creators of knowledge rather than just being recipients of knowledge (25). Thus, using project management can benefit both the management and scientific outcomes of health and medical students and researchers (26-27).

The last questionnaire section covered the assessment of students' perceptions about teamwork. The results reflected the enhancement of teamwork-based skills as follows: actively listening to other team members; asking and responding to team members' requests; assertiveness when exchanging ideas with group members; facing challenges through team collaborative work; and working in a diverse group rather than doing individual work. This indicates higher student engagement, satisfaction and long-term learning by working in teams, which is a feature found in some other teaching strategies, such as TBL. This finding was in agreement with Faezi et al. (28). They reported that TBL can increase learners' participation and satisfaction with a course, which could lead to deeper learning, long-term knowledge retention and better performance regarding practical knowledge (28-29).

In this current study, a positive correlation between students' perception of the questionnaire's four parts and their GPA in the molecular biology course was found, which reflects the effectiveness of
PjBL compared to the traditional didactic method, evidenced by better academic achievement. This finding is in agreement with Ilter (13) and Chen and Yang (30).

The limitations of this current study could be the unavailability of some of the learning facilities, such as limited classrooms for small-group work, having only a few oncampus computers and students being overwhelmed by their scheduled lectures and exams. Another important limitation is the limited library resources that provide students with learning resources.

\section{CONCLUSION}

From the results of the current study, it can be concluded that $\mathrm{PjBL}$ was an effective and successful tool in the active learning process in the molecular biology course. The PjBL tool could improve students' communication and project management skills. Also, this teaching strategy encourages teamwork activity. Therefore, this study recommends the implementation of $\mathrm{PjBL}$ in teaching medical biochemistry and molecular biology to benefit from the opportunities of $\mathrm{PjBL}$ in education.

\section{ACKNOWLEDGEMENTS}

We would like to acknowledge all the second-year pharmacy students who actively participated in completing the questionnaires.

\section{ETHICAL APPROVAL}

This study was approved by the Biomedical Ethics Research Committee of King Abdulaziz University (Reference No. 14919). 


\section{REFERENCES}

1. Ahluwalia G, Aggrawal, D. Language learning with internet-based projects: a student-centred approach for engineering students. ESP World. 2010;1(27):9.

2. Doppelt Y. Implementing and assessment of PBL in a flexible environment. International Journal of Technology and Design Education. 2003;13:255-72. https://doi.org/ 10.1023/A:1026125427344

3. Bell S. Project-based learning for the $21 \mathrm{st}$ century: skills for the future. The Clearing House: A Journal of Educational Strategies, Issues and Ideas. 2010;83:39-43. https://doi .org/10.1080/00098650903505415

4. Kloppenborg TJ, Baucus MS. Project management in local non-profit organizations: engaging students in problem based learning. Journal of Management Education. 2004;28(5):610-30. https://doi .org/10.1177/1052562904266008

5. Treleavan L, Voola R. Integrating the development of graduate attributes through constructive alignment. Journal of Marketing Education. 2008;30(2):160-73. https://doi. org/10.1177/0273475308319352

6. Nordin, MK. Enhancing graduate employability: issues, concerns and the way forward. Kuala Lumpur: Minister of Higher Education; 2009.

7. Sang VN, Van NT. Student perception of using project-based learning (PjBL): a case study in Universiti Teknologi Malaysia (UTM). In: Fook C, Sidhu G, Narasuman S, Fong L, Abdul Rahman S, editors. 7th International Conference on University Learning and Teaching (InCULT 2014) Proceedings. Singapore: Springer; 2016. p. 387-97. https://doi.org/10.1007/978-981 -287-664-5_31

8. Berends H, Boersma K, Weggeman M. The structuration of organizational learning. Human Relations. 2003;56(9):1035-56. https://doi.org/10.1177/0018726703569001
9. Mergendoller JR. Project based learning handbook. 2nd ed. Novato, CA: Buck Institute for Education; 2006.

10. Thomas JW. A review of research on projectbased learning. San Rafael, CA: Autodesk Foundation; 2000.

11. Kirschner PA, Clark RE. Why minimal guidance during instruction does not work: an analysis of the failure of constructivist, discovery, problem-based, experiential, and inquiry-based teaching. Learning. 2006;41(2):75-86. https://doi.org/10.1207/ s15326985ep4102_1

12. Fox TG. Project-based learning in primary grades [dissertation]. United States: University of Michigan; 2013.

13. Ilter $\ddot{\mathrm{A}}^{\circ}$. A study on the efficacy of projectbased learning approach on social studies education: conceptual achievement and academic motivation. Educational Research and Reviews. 2014; 9(15):487-97. https://doi.org/10.5897/ERR2014.1777

14. Shernoff DJ, Sinha S, Bressler DM, Schultz D. Teacher perceptions of their curricular and pedagogical shifts: outcomes of a project-based model of teacher professional development in the next generation science standards. Front Psychol. 2017;16(8):989. https://doi.org/10.3389/fpsyg.2017.00989

15. Bowen L, Marshall M, Murdoch-Eaton D. Medical student perceptions of feedback and feedback behaviors within the context of the "educational alliance." Acad Med. 2017;92(9):1303-12. https://doi.org/10.1097/ ACM.0000000000001632

16. Boud D. Feedback: ensuring that it leads to enhanced learning. Clin Teach. 2015;12:3-7. https://doi.org/10.1111/tct.12345

17. Saurabh RS, Prateek SS, Jegadeesh R. Effective feedback: an indispensable tool for improvement in quality of medical education. J Pedago Deve. 2014;4(1):12-20. 
18. Ansari T, Usmani A. Students perception towards feedback in clinical sciences in an outcome-based integrated curriculum. Pak J Med Sci. 2018;34(3):702-9. https://doi.org/ $10.12669 /$ pims.343.15021

19. Gavin K. Case study of a project-based learning course in civil engineering design. Eur J Eng Educ. 2011;36(6):547-58. https://doi.org/10.1080/03043797.2011.624 173

20. Bender WN. Project-based learning: differentiating instruction for the $21 \mathrm{st}$ century. Thousand Oaks, USA: Corwin Press; 2012.

21. Si J. Course-based research experience of undergraduate medical students through project-based learning. Korean J Med Educ. 2020;32(1):47-57. https://doi.org/10.3946/ kjme.2020.152

22. Ishikawa $H$, Hashimoto $H$, Kinoshita $M$, Yano E. Can nonverbal communication skills be taught? Med Teach. 2010;32(10):860-3. https://doi.org/10.3109/ 01421591003728211

23. Liu C, Lim RL, McCabe KL, Taylor S, Calvo RA. A web-based telehealth training platform incorporating automated nonverbal behavior feedback for teaching communication skills to medical students: a randomized crossover study. J Med Internet Res. 2016;18(9):e246. https://doi .org/10.2196/jmir.6299

24. Park KH, Park SG. The effect of communication training using standardized patients on nonverbal behaviors in medical students. Korean J Med Educ. 2018;30(2):153-9. https://doi.org/10.3946/ kjme. 2018.90
25. Ojiako U, Ashleigh M, Chipulu M, Maguire S. Learning and teaching challenges in project management. International Journal of Project Management. 2011;29(3):26878. https://doi.org/10.1016/j.ijproman.2010 .03 .008

26. Payne JM, France KE, Henley N, D'Antoine HA, Bartu AE, Elliott EJ, et al. Researchers' experience with project management in health and medical research: results from a post-project review. BMC Public Health 2011;2(11):424. https://doi .org/10.1186/1471-2458-11-424

27. Goldman J, Kuper A, Baker GR, Bulmer B, Coffey M, Jeffs L, et al. Experiential learning in project-based quality improvement education: questioning assumptions and identifying future directions. Acad Med. 2020;95(11):1745-54. https://doi.org/10 .1097/ACM.0000000000003203

28. Faezi ST, Moradi K, Ghafar Rahimi Amin A, Akhlaghi M, Keshmiri F. The effects of team-based learning on learning outcomes in a course of rheumatology. J Adv Med Educ Prof. 2018;6(1):22-30.

29. Kim DH, Jung-Ho Lee JH, Kim SA. The pharmacology course for preclinical students using team-based learning. Korean J Med Educ. 2020;32(1):35-46. https://doi .org/10.3946/kjme.2020.151

30. Chen $\mathrm{CH}$, Yang YC. Revisiting the effects of project-based learning on students' academic achievement: a meta-analysis investigating moderators. Educational Research Review. 2019;26:71-81. https://doi .org/10.1016/j.edurev.2018.11.001 